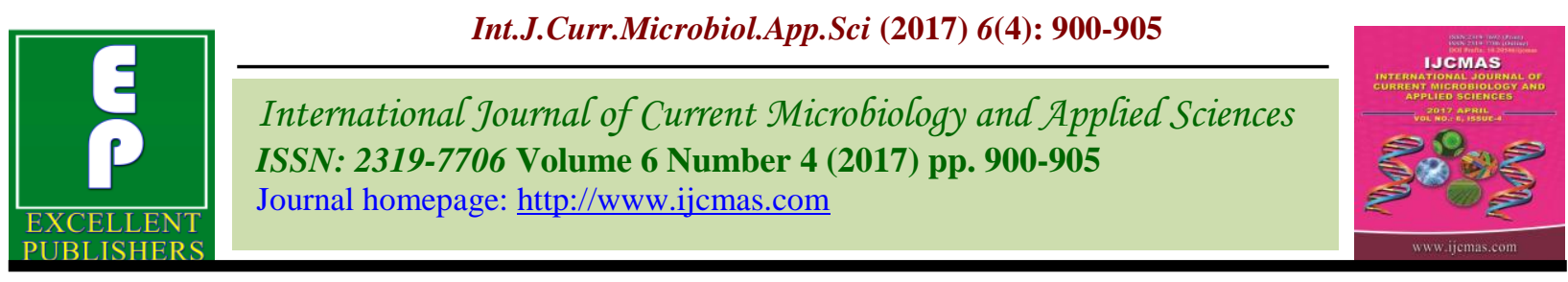

Original Research Article

https://doi.org/10.20546/ijcmas.2017.604.114

\title{
Bio-Efficacy of Sequential Application of Herbicides on Weeds and Yield in Direct Seeded Rice (Oryza sativa)
}

\author{
Ajay Singh*, D.P. Nandal and S.S. Punia \\ Department of Agronomy, CCS Haryana Agricultural University, Hisar 125 004, India \\ *Corresponding author
}

\begin{tabular}{|c|c|}
\hline & A B S T R A C T \\
\hline Keywords & $\begin{array}{l}\text { A field experiment was conducted during kharif } 2012 \text { to evaluate the efficacy of different } \\
\text { pre and post emergence herbicides in direct seeded rice. The chemical treatments included }\end{array}$ \\
\hline $\begin{array}{l}\text { Direct seeded rice, } \\
\text { effective tillers, } \\
\text { filled grains, grain } \\
\text { yield, herbicides, } \\
\text { weed control } \\
\text { efficiency. }\end{array}$ & $\begin{array}{l}\text { two pre-emergence herbicides namely pendimethalin } 1000 \mathrm{~g} / \mathrm{ha} \text { and oxadiargyl } 100 \mathrm{~g} / \mathrm{ha} \\
\text { and four post-emergence herbicides viz. bispyribac-sodium } 25 \mathrm{~g} / \mathrm{ha} \text {, fenoxaprop } 67 \mathrm{~g} / \mathrm{ha} \text {, } \\
\text { ethoxysulfuron } 18.75 \mathrm{~g} / \mathrm{ha} \text { and chlorimuron-ethyl +metsulfuron-methyl RM } 4 \mathrm{~g} / \mathrm{ha} \text { at } 25 \\
\text { DAS. Weed free and weedy check were also included. Among chemical treatments, } \\
\text { sequential application of pendimethalin } 1000 \mathrm{~g} / \mathrm{ha} \mathrm{fb} \text { bispyribac-sodium } 25 \mathrm{~g} / \mathrm{ha} \text { and } \\
\text { chlorimuron-ethyl+ metsulfuron-methyl RM } 4 \mathrm{~g} / \mathrm{ha} \text { produces minimum density of }\end{array}$ \\
\hline Article Info & $\begin{array}{l}\text { Echinochloa glabrescens, Cyperus spp. and Ammania spp. at } 45 \text { DAS which was } \\
\text { statistically at par with weed free. This treatment also had highest efficacy against }\end{array}$ \\
\hline $\begin{array}{l}\text { Accepted: } \\
\text { 06 March } 2017 \\
\text { Available Online: } \\
10 \text { April } 2017\end{array}$ & $\begin{array}{l}\text { Echinochloa glabrescens, Cyperus spp. and Ammania spp. at } 45 \text { DAS. Sequential } \\
\text { application of pendimethalin } 1000 \mathrm{~g} / \mathrm{ha} f b \text { bispyribac-sodium } 25 \mathrm{~g} / \mathrm{ha} \text { and chlorimuron- } \\
\text { ethyl+ metsulfuron-methyl RM } 4 \mathrm{~g} / \mathrm{ha} \text { gave maximum number of effective tillers (209.3), } \\
\text { filled grains/panicle (83.7), grain yield ( } 3.97 \mathrm{t} / \mathrm{ha}) \text { and } \mathrm{B}: \mathrm{C}(2.37) \text { among chemical weed } \\
\text { control treatments which was at par with weed free. }\end{array}$ \\
\hline
\end{tabular}

\section{Introduction}

Rice (Oryza sativa L.) is one of the most important cereal crops of India and a staple food of more than $65 \%$ of its population. In India, the crop occupies an area of nearly 44.1 $\mathrm{m}$ ha with total production of $105.5 \mathrm{~m} \mathrm{t}$ and productivity of $2391 \mathrm{~kg} / \mathrm{ha}$ (Anonymous, 2014).

In India, it is commonly grown by transplanting seedlings into puddled soil which benefits rice by reducing water percolation losses, controlling weeds, facilitating easy seedling establishment and creating anaerobic conditions to enhance nutrient availability (Bhurer et al., 2013). But, repeated puddling adversely affects soil physical properties by destroying soil aggregates, reducing permeability in subsurface layers and forming hard-pans at shallow depths (Sharma et al., 2003). All these factors demand a major shift from puddle-transplanted rice (CT-TPR) to direct seeding of rice (DSR) in irrigated areas. In addition, DSR matures earlier than the transplanted rice allowing timely planting of succeeding wheat crop (Singh et al., 2006). DSR by eliminating puddling and continuous submergence of fields reduces the overall water application for rice culture. But weed control is major limitation for the success of 
DSR (Chauhan, 2012). Aerobic systems are subjected to much higher weed pressure than conventional puddled transplanting system (Rao et al., 2007) in which weeds are suppressed by standing water and by transplanted rice seedlings, which have a "head start" over germinating weed seedlings (Moody, 1983). Success of DSR depends largely on weed control especially with chemical methods. Various herbicides have been used for controlling weeds in DSR but efficiency of chemical methods based on single herbicide treatment may be unsatisfactory because of their narrow spectrum of weed control. Therefore, application of several herbicides in sequence can be more useful (Chauhan and Yadav, 2013). So, this experiment, involving multitudinous herbicide combinations was undertaken to achieve an effective broadspectrum weed control.

\section{Materials and Methods}

The study was conducted during the kharif 2012 at Students' Farm of College of Agriculture, CCS Haryana Agricultural University; campus Kaul (Kaithal). The soil of the experiment field was clay loam in texture and slightly alkaline in reaction. The soil was low in organic carbon, low in available nitrogen, medium in available phosphorus and high in available potassium. The treatments included pre and post emergence herbicides $\left(\mathrm{T}_{1}\right.$ : pendimethalin $1000 \mathrm{~g} / \mathrm{ha} f b$ bispyribac sodium $25 \mathrm{~g} / \mathrm{ha}, \mathrm{T}_{2}$ : pendimethalin $1000 \mathrm{~g} / \mathrm{ha} \mathrm{fb}$ bispyribac sodium $25 \mathrm{~g} / \mathrm{ha}$ +ethoxysulfuron $18.75 \mathrm{~g} / \mathrm{ha}, \mathrm{T}_{3}$ : pendimethalin $1000 \mathrm{~g} / \mathrm{ha} \mathrm{fb}$ bispyribac sodium $25 \mathrm{~g} / \mathrm{ha}+$ chlorimuron-ethyl and metsulfuronmethyl ready mix $4 \mathrm{~g} / \mathrm{ha}, \mathrm{T}_{4}$ : pendimethalin $1000 \mathrm{~g} / \mathrm{ha} f b$ fenoxaprop $67 \mathrm{~g} / \mathrm{ha}, \mathrm{T}_{5}$ : pendimethalin $1000 \mathrm{~g} / \mathrm{ha} \mathrm{fb}$ fenoxaprop 67 $\mathrm{g} / \mathrm{ha}+$ ethoxysulfuron $18.75 \mathrm{~g} / \mathrm{ha}, \mathrm{T}_{6}$ : pendimethalin $1000 \mathrm{~g} / \mathrm{ha} \mathrm{fb}$ fenoxaprop 67 $\mathrm{g} / \mathrm{ha}+$ chlorimuron-ethyl and metsulfuronmethyl ready mix $4 \mathrm{~g} / \mathrm{ha}, \mathrm{T}_{7}$ : oxadiargyl 100 $\mathrm{g} / \mathrm{ha} f b$ bispyribac sodium $25 \mathrm{~g} / \mathrm{ha}, \mathrm{T}_{8}$ : oxadiargyl $100 \mathrm{~g} / \mathrm{ha} f b$ bispyribac sodium 25 $\mathrm{g} / \mathrm{ha}+$ ethoxysulfuron $18.75 \mathrm{~g} / \mathrm{ha}, \mathrm{T}_{9}$ : oxadiargyl $100 \mathrm{~g} / \mathrm{ha} f b$ bispyribac sodium 25 $\mathrm{g} / \mathrm{ha}+$ chlorimuron-ethyl and metsulfuronmethyl ready mix $4 \mathrm{~g} / \mathrm{ha}, \mathrm{T}_{10}$ : oxadiargyl 100 $\mathrm{g} / \mathrm{ha} f b$ fenoxaprop $67 \mathrm{~g} / \mathrm{ha}, \mathrm{T}_{11}$ : oxadiargyl $100 \mathrm{~g} / \mathrm{ha} f b$ fenoxaprop $67 \mathrm{~g} / \mathrm{ha}+$ ethoxysulfuron $18.75 \mathrm{~g} / \mathrm{ha}, \mathrm{T}_{12}$ : oxadiargyl $100 \mathrm{~g} / \mathrm{ha} f b$ fenoxaprop $67 \mathrm{~g} / \mathrm{ha}+$ chlorimuron-ethyl and metsulfuron-methyl ready mix $4 \mathrm{~g} / \mathrm{ha}$ ) which were compared with weedy check and weed free treatments in randomized complete block design with three replications (Table 1). Rice variety PUSA 1121 was seeded on $19^{\text {th }}$ June 2012 in rows $22.5 \mathrm{~cm}$ apart using seed drill. Herbicides were applied as spray in aqueous media at the rate of 500 litre of water per ha, using a Knapsack sprayer with a flat fan nozzle. The amount of herbicides and water was computed on the basis of gross area to be sprayed. In weed free plots, weeds were removed as and when required after sowing, manually. Nitrogen, phosphorus, potassium and zinc were applied at the rate of 60, 30, 30 and $25 \mathrm{~kg} / \mathrm{ha}$ respectively through urea, diammonium phosphate, muriate of potash and $\mathrm{ZnSO}_{4}$. Half dose of nitrogen and full dose of phosphorus, potassium and $\mathrm{ZnSO}_{4}$ were drilled at the time of sowing. Remaining half of nitrogen was top dressed in two equal splits; first at active tillering stage and second at panicle initiation stage. Weed density (number $/ \mathrm{m}^{2}$ ) were recorded species wise in each plot using quadrate of $50 \mathrm{~cm} \times 50 \mathrm{~cm}$ $\left(0.25 \mathrm{~m}^{2}\right)$ from the area selected randomly for observations. The weed control efficiency (WCE) was calculated by using the following formula (Singh et al., 2000).

\section{$\mathrm{WCE}=(\mathrm{DMC}-\mathrm{DMT}) / \mathrm{DMC} \times 100$}

Where, DMC is dry matter of weeds $(\mathrm{g})$ in weedy check and DMT is dry matter of weeds (g) in a particular treatment. 
Table.1 Effect of different weed control treatments on weed density and weed control efficiency at 45 DAS in direct seeded rice

\begin{tabular}{|c|c|c|c|c|c|c|c|c|c|c|c|}
\hline & Treatment & Dose & Time of & & d density $(\mathrm{Nc}$ & $\left.\mathrm{m}^{2}\right) 45 \mathrm{DA}$ & & Weed & control effici & ncy $(\%) 45$ & $\overline{\mathrm{AS}}$ \\
\hline & & & (DAS) & $\begin{array}{l}\text { Echinochloa } \\
\text { glabrescens }\end{array}$ & $\begin{array}{l}\text { Leptochloa } \\
\text { chinensis }\end{array}$ & $\begin{array}{l}\text { Cyperus } \\
\text { spp. }\end{array}$ & $\begin{array}{l}\text { Ammania } \\
\text { baccifera }\end{array}$ & $\begin{array}{l}\text { Echinochloa } \\
\text { glabrescens }\end{array}$ & $\begin{array}{l}\text { Leptochloa } \\
\text { chinensis }\end{array}$ & $\begin{array}{l}\text { Cyperus } \\
\text { spp. }\end{array}$ & $\begin{array}{l}\text { Ammania } \\
\text { baccifera }\end{array}$ \\
\hline T1 & Pendimethalin $f b$ bispyribac-Na & $1000 \mathrm{fb} 25$ & $3 f b 25$ & $3.3(9.9)$ & $5.6(30.8)$ & $5.6(30.5)$ & $3.2(9.3)$ & 75.3 & 44.9 & 58.0 & 45.1 \\
\hline $\mathrm{T} 2$ & $\begin{array}{l}\text { Pendimethalin } f b \text { bispyribac-Na } \\
\text { +ethoxysulfuron }\end{array}$ & $\begin{array}{l}1000 \mathrm{fb} 25 \\
+18.75\end{array}$ & $3 f b 25$ & $3.2(9.2)$ & $5.1(25.5)$ & $2.3(5.1)$ & $2.5(5.3)$ & 77.0 & 54.5 & 93.0 & 70.2 \\
\hline T3 & $\begin{array}{l}\text { Pendimethalin } f b \text { bispyribac- } \mathrm{Na}+ \\
\text { metsulfuron methyl + chlorimuron } \\
\text { ethyl RM (Almix) }\end{array}$ & $\begin{array}{l}1000 f b 25 \\
+4\end{array}$ & $3 f b 25$ & $2.9(7.2)$ & $5.5(29.6)$ & $2.2(4.4)$ & $1.8(2.7)$ & 82.0 & 47.1 & 93.9 & 84.9 \\
\hline $\mathrm{T} 4$ & Pendimethalin $f b$ fenoxaprop & $1000 \mathrm{fb} 67$ & $3 f b 25$ & $4.2(17.2)$ & $2.3(4.1)$ & $5.3(28.2)$ & $3.2(9.3)$ & 56.9 & 92.7 & 61.2 & 46.2 \\
\hline T5 & $\begin{array}{l}\text { Pendimethalin } f b \text { fenoxaprop } \\
\text { +ethxysulfuron }\end{array}$ & $\begin{array}{l}1000 \mathrm{fb} 67 \\
+18.75\end{array}$ & $3 f b 25$ & 4.1(16.4) & $2.4(4.7)$ & $2.4(6.0)$ & $2.3(5.3)$ & 58.9 & 91.6 & 91.7 & 69.3 \\
\hline T6 & $\begin{array}{l}\text { Pendimethalin } f b \text { fenoxaprop }+ \\
\text { metsulfuron methyl + chlorimuron } \\
\text { ethyl RM (Almix) }\end{array}$ & $\begin{array}{l}1000 f b 67 \\
+4\end{array}$ & $3 f b 25$ & $3.9(14.8)$ & $2.4(4.5)$ & $2.4(5.5)$ & $1.8(2.7)$ & 62.9 & 91.9 & 92.5 & 84.2 \\
\hline $\mathrm{T} 7$ & Oxadiargyl $f b$ bispyribac- $\mathrm{Na}$ & $100 \mathrm{fb} 25$ & $3 f b 25$ & $3.7(13.1)$ & $5.6(30.3)$ & $5.6(30.7)$ & $3.6(12.0)$ & 67.3 & 45.9 & 57.8 & 30.7 \\
\hline $\mathrm{T} 8$ & $\begin{array}{l}\text { Oxadiargyl } f b \text { bispyribac-Na } \\
\text { +ethoxysulfuron }\end{array}$ & $\begin{array}{l}100 \mathrm{fb} \mathrm{25} \\
+18.75 \\
\end{array}$ & $3 f b 25$ & $3.7(12.8)$ & $5.7(31.5)$ & $2.6(7.2)$ & $3.0(8.0)$ & 67.9 & 43.7 & 90.1 & 53.8 \\
\hline T9 & $\begin{array}{l}\text { Oxadiargyl } f b \text { bispyribac-Na }+ \\
\text { metsulfuron methyl }+ \text { chlorimuron } \\
\text { ethyl RM (Almix) }\end{array}$ & $\begin{array}{l}100 f b 25 \\
+4\end{array}$ & $3 f b 25$ & $3.5(11.2)$ & $6.0(35.7)$ & $2.5(6.1)$ & $2.7(6.7)$ & 71.9 & 36.1 & 91.6 & 61.5 \\
\hline T10 & Oxadiargyl $f b$ fenoxaprop & $100 \mathrm{fb} 67$ & $3 f b 25$ & $4.7(21.2)$ & $2.4(4.5)$ & $6.7(43.7)$ & $3.8(13.3)$ & 46.9 & 91.9 & 39.9 & 23.1 \\
\hline T11 & $\begin{array}{l}\text { Oxadiargyl } f b \text { fenoxaprop+ } \\
\text { ethoxysulfuron }\end{array}$ & $\begin{array}{l}100 \mathrm{fb} 67 \\
+18.75 \\
\end{array}$ & $3 f b 25$ & $4.5(20.1)$ & $2.6(5.7)$ & $2.6(7.3)$ & $3.0(8.0)$ & 49.7 & 89.7 & 89.9 & 52.9 \\
\hline T12 & $\begin{array}{l}\text { Oxadiargyl } f b \text { fenoxaprop }+ \\
\text { metsulfuron methyl + chlorimuron } \\
\text { ethyl RM (Almix) }\end{array}$ & $\begin{array}{l}100 \mathrm{fb} 67 \\
+4\end{array}$ & $3 f b 25$ & $4.4(18.4)$ & $2.6(5.6)$ & $2.5(6.7)$ & $2.7(6.7)$ & 53.9 & 90.0 & 90.8 & 60.7 \\
\hline T13 & Weed free & $1000 \mathrm{fb} 25$ & $3 f b 25$ & $1.0(0.0)$ & $1.0(0.0)$ & $1.0(0.0)$ & $1.0(0.0)$ & 100.0 & 100.0 & 100.0 & 100.0 \\
\hline T14 & Weedy check & $\begin{array}{l}1000 \mathrm{fb} 25 \\
+18.75\end{array}$ & $3 f b 25$ & $7.0(48.4)$ & $7.5(56.0)$ & $8.6(72.6)$ & $4.2(17.3)$ & 0.0 & 0.0 & 0.0 & 0.0 \\
\hline & SEm \pm & & & 0.2 & 0.2 & 0.3 & 0.3 & - & - & - & - \\
\hline & $\mathrm{CD}(\mathrm{P}=0.05)$ & & & 0.7 & 0.6 & 1.0 & 0.8 & - & - & - & - \\
\hline
\end{tabular}

*Original values are in parenthesis and before statistical analysis were subjected to square root transformation $(\sqrt{ } \mathrm{x}+1)$ 


\section{Int.J.Curr.Microbiol.App.Sci (2017) 6(4): 900-905}

Table.2 Effect of different weed control treatments on yield attributes, yield and economics of direct seeded rice

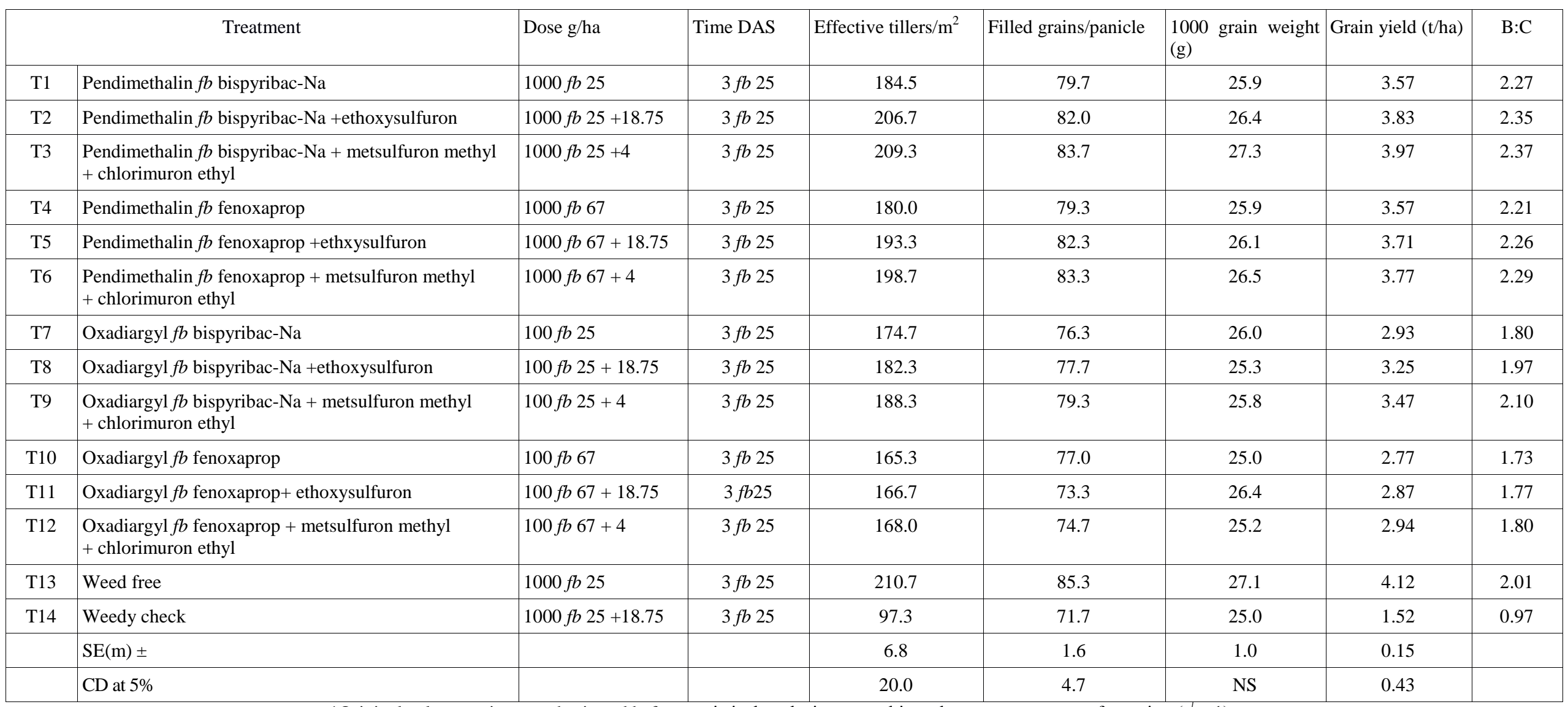

*Original values are in parenthesis and before statistical analysis were subjected to square root transformation $(\sqrt{\mathrm{x}}+1)$ 
The data was analyzed using analysis of variance (ANOVA) as applicable to randomized complete block design. The significance of the treatment effects was determined using F-test at 5\% significance level. Data on number and dry weight of weeds were subjected to square-root $\sqrt{ }(x+0.5)$ transformation before analysis of variance.

\section{Results and Discussion}

\section{Weed population and dry weight}

Weed flora of the experimental field was mainly dominated by Cyperus difformis, Cyperus rotundus, Leptochloa chinensis, Echinochloa glabrescens, Eclipta alba and Ammania spp.

All the herbicidal treatments significantly reduced the density of all weed species compared to weedy check at 45 DAS $(p=0.05)$. Among herbicidal treatments preemergence application of pendimethlin 1000 $\mathrm{g} / \mathrm{ha} f b$ bispyribac-sodium $25 \mathrm{~g} / \mathrm{ha}$ and chlorimuron-ethyl + metsulfuron-methyl RM $4 \mathrm{~g} / \mathrm{ha}$ gave minimum density of $E$. glabrescens, Cyperus spp. and Ammania spp. at 45 DAS. The weed density in this treatment was statistically at par with weed free treatment (Table 1). This may be due to effective control of weeds during early stage by pendimethalin $1000 \mathrm{~g} / \mathrm{ha}$ and thereafter better control by bispyribac-sodium $25 \mathrm{~g} / \mathrm{ha}$ and chlorimuron-ethyl + metsulfuron-methyl $4 \mathrm{~g} / \mathrm{ha}$ at later stage of crop growth. The minimum density of L. chinensis at 45 DAS was however obtained under application of pendimethalin $1000 \mathrm{~g} / \mathrm{ha}$ as pre-emergence and fenoxaprop $67 \mathrm{~g} / \mathrm{ha}$ and chlorimuronethyl + metsulfuron-methyl RM $4 \mathrm{~g} / \mathrm{ha}$ as post-emergence. This may be due to excellent control of Leptochloa chinensis by fenoxprop $67 \mathrm{~g} / \mathrm{ha}$. Similar control of L. chinensis by fenoxaprop $56.25 \mathrm{~g} / \mathrm{ha}$ was recorded by Singh et al., (2004). The weed control efficiency of different weeds also followed the similar pattern as of weed density. Among all chemical treatments, highest weed control efficiency at 45 DAS was achieved by preemergence application of pendimethlin 1000 $\mathrm{g} / \mathrm{ha} f b$ bispyribac-sodium $25 \mathrm{~g} / \mathrm{ha}$ and chlorimuron-ethyl + metsulfuron-methyl RM $4 \mathrm{~g} / \mathrm{ha}$ as post-emergence. The efficiency of this treatment was $93.9 \%$ for Cyperus spp, 82 $\%$ for E. glabrescens and $84.9 \%$ for Ammania spp. For L. chinensis highest weed control efficiency $(92.1 \%)$ at 45 DAS was observed with pendimethalin $1000 \mathrm{~g} / \mathrm{ha}$ as pre-emergence $f b$ fenoxaprop $67 \mathrm{~g} / \mathrm{ha}$ as post emergence (Table 1).

\section{Crop growth and yield}

All the treatments produced significantly higher number of effective tillers, filled grains/ panicle and grain yield than weedy check $(p=0.05)$ (Table 2). Weed free treatment were recorded highest for number of effective tillers (210), filled grains/panicle (85.3) and grain yield (4.12 t/ha). Among all herbicidal treatment, sequential application of pendimethalin $1000 \mathrm{~g} / \mathrm{ha} \mathrm{fb}$ bispyribac sodium $25 \mathrm{~g} / \mathrm{ha}$ and metsulfuron methyl + chlorimuron ethyl $4 \mathrm{~g} / \mathrm{ha}$ had highest number of effective tillers (209.3), filled grains/panicle (83.7) and grain yield (3.97 t/ha) which was at par with weed free treatment while minimum number of effective tillers $/ \mathrm{m}^{2}(165.3)$, grain yield (2.77 t/ha) was obtained with application of oxadiargyl 100 $\mathrm{g} /$ ha followed by fenoxaprop $67 \mathrm{~g} / \mathrm{ha}$. Similar results on effective tillers, filled grains/panicle and yield of direct seeded rice were obtained by Ganie et al., (2014). The effect of different weed control treatments on 1000 grain weight was found non-significant.

\section{Economics}

The highest B: C (2.37) was obtained under sequential application of pendimethalin 1000 $\mathrm{g} / \mathrm{ha} f b$ bispyribac sodium $25 \mathrm{~g} / \mathrm{ha}$ and metsulfuron methyl + chlorimuron ethyl 4 
$\mathrm{g} / \mathrm{ha}$ which was higher than under weed free treatment (2.01) (Table 2). This is due to higher cost of cultivation by employing manual weeding in weed free treatment.

\section{References}

Anonymous.

2014. https://www.india.stat.com

Bhurer, K.P., Yadav, D.N., Ladha, J.K., Thapa, R.B. and Pandey, K.R. 2013. Efficacy of various herbicides to control weeds in dry direct seeded rice (Oryza sativa L.). Glob. J. Bio. Agri. Health Sci., 2(4): 205-212.

Chauhan, B.S. 2012. Weed ecology and weed management strategies for dry-seeded rice in Asia. Weed Tech., 26: 1-13.

Chauhan, B.S. and Yadav, A. 2013. Weed management approaches for dry-seeded rice in India: a review. Ind. J. of Weed Sci., 45(1): 1-6.

Ganie, Z.A., Singh, S. and Singh, S. 2014. Integrated weed management in dryseeded rice. Ind. J. Weed Sci., 46(2): 7273 .

Moody, K. 1983. The status of weed control in Asia. FAO Plant Prot. Bull., 30: 119120.
Rao, A.N., Johnson, D.E., Shivprasad, B., Ladha, J.K. and Mortimer, A.M. 2007. Weed management in direct-seeded rice. Adva. Agro., 93: 153-255.

Sharma, P.K., Ladha, J.K. and Bhushan, L. 2003. Soil physical effects of puddling in rice-wheat cropping systems. In "Improving the productivity and sustainability of rice-wheat systems: Issues and Impacts" (J K Ladha, J E Hill, J M Duxbury, R K Gupta and R J Buresh, Eds.), pp. 97-113. ASA, CSSA, SSSA, Madison, WI, ASA Special Publication 65.

Singh, S., Bhusan, L., Ladha, J.K., Gupta, R. K., Rao, A.N. and Shivprasad, B. 2006. Weed management in dry-seeded rice (Oryza sativa L.) cultivated in furrow irrigated raised bed planting system. Crop Prot., 25(5): 487-495.

Singh, T., Brar, L.S. and Walia, U.S. 2000. Comparative efficiency of herbicides for weed control in chickpea (Cicer arientum L.). Crop Res., 19(1): 1-5.

Singh, V.P., Singh, G. and Singh, M. 2004. Effect of fenoxaprop-p-ethyl on transplanted rice and associated weeds. Ind. J. Weed Sci., 36: 190-192.

\section{How to cite this article:}

Ajay Singh, D.P. Nandal and S.S. Punia. 2017. Bio-Efficacy of Sequential Application of Herbicides on Weeds and Yield in Direct Seeded Rice (Oryza sativa). Int.J.Curr.Microbiol.App.Sci. 6(4): 900-905. doi: https://doi.org/10.20546/ijcmas.2017.604.114 